\title{
INSIDER EARLY SALES IN IPO FIRMS
}

Tianze Li, New York Institute of Technology, U.S.A.

dx.doi.org/10.18374/JABE-20-3.5

\begin{abstract}
The paper investigates the determinants of insider early sales (i.e., before the common lock-up expiration date) in IPO firms. We find that IPOs experiencing larger abnormal stock returns, with higher market-to-book (M/B) ratio, and backed by Venture Capitalists (VCs) are more likely to be involved in insider early sales. These results are consistent with the market timing hypothesis and liquidity need hypothesis. More importantly, consistent with strategic underpricing hypothesis, we find that magnitude of underpricing exerts a more statistically and economically significant influence on the insider early sales decision. Moreover, the relation is more pronounced for a group of insiders consisting of top management team only. We also find that the probability of insider early sales is positively associated with the underwriter reputation.
\end{abstract}

Keywords: IPO, insider trading, underpricing 